\title{
Chemotactic response of marine bacteria to the extracellular products of Synechococcus and Prochlorococcus
}

\author{
J. R. Seymour ${ }^{1,2,3, *}$, T. Ahmed ${ }^{1}$, W. M. Durham ${ }^{1}$, R. Stocker $^{1}$ \\ ${ }^{1}$ Ralph M. Parsons Laboratory, Department of Civil and Environmental Engineering, Massachusetts Institute of Technology, \\ 77 Massachusetts Ave., Cambridge, Massachusetts 02139, USA \\ ${ }^{2}$ School of Biological Sciences, Flinders University, Adelaide, South Australia, 5001, Australia \\ ${ }^{3}$ Present address: Plant Functional Biology and Climate Change Cluster (C3), University of Technology, Sydney, PO Box 123, \\ Broadway, New South Wales 2007, Australia
}

\begin{abstract}
The cyanobacterial genera Prochlorococcus and Synechococcus are key phototrophic organisms in the open ocean, and ecological interactions between these groups and heterotrophic bacteria have fundamental importance for marine carbon and nutrient cycling. We applied a microfluidic chemotaxis assay to study the chemotactic response of 3 marine bacterial isolates (Pseudoalteromonas haloplanktis, Vibrio alginolyticus and Silicibacter sp. TM1040) to the chemical products of Synechococcus elongatus and Prochlorococcus marinus MED 4Ax. In the ocean, chemical products from these cyanobacteria may be released into the water column via extracellular exudation or cell lysis. Strong and rapid chemotactic responses by all 3 bacterial strains occurred in reaction to the Synechococcus products. P. haloplanktis cells exhibited the strongest attraction, accumulating within the chemoattractant band in concentrations of up to 9-fold above background levels. Positive chemotaxis to Prochlorococcus chemical products also occurred, with P. haloplanktis and Silicibacter sp. TM1040 exhibiting the strongest responses. These observations indicate that marine bacteria can exhibit behavioural responses to the chemical products of Synechococcus and Prochlorococcus, which may support ecological associations between these important populations of marine prokaryotes in the environment.
\end{abstract}

KEY WORDS: Chemotaxis $\cdot$ Cyanobacteria $\cdot$ Heterotrophic bacteria $\cdot$ DOC

\section{INTRODUCTION}

Marine bacteria are predicted to cluster around living phytoplankton cells, to take advantage of microzones of exuded dissolved organic carbon (DOC; Azam \& Ammerman 1984), and to aggregate within patches of DOC released from lysed phytoplankton cells (Blackburn et al. 1998). This active clustering requires chemotaxis, i.e. the ability to direct movement in response to chemical stimuli. Chemotaxis is a common phenotype among marine bacteria (MalmcronaFriberg et al. 1990, Barbara \& Mitchell 2003a), and the chemical products of phytoplankton are potent chemoattractants for natural communities (Bell \& Mitchell
1972) and isolated species (Miller et al. 2004) of bacteria. As a consequence of chemotactic behaviour, heterotrophic bacteria often occur in close spatial associations with phytoplankton cells (Alavi et al. 2001, Barbara \& Mitchell 2003b). Chemotaxis can therefore play an important role in bacteria-phytoplankton interactions, which in turn shape carbon and nutrient cycling in the upper ocean.

While tight ecological associations between bacteria and eukaryotic phytoplankton are well established, prokaryotic phytoplankton are dominant across much of the open ocean. In particular, the 2 cyanobacterial genera Prochlorococcus and Synechococcus often constitute the bulk of photosynthetic biomass and are 
responsible for a significant, but variable, proportion of primary production in oligotrophic waters (Waterbury et al. 1979, Chisholm et al. 1988, Vaulot et al. 1995, Fernández et al. 2003). Cyanobacteria exude DOC (Paerl \& Pinckney 1996, Bertilsson et al. 2005) and as a consequence of bacterial chemotaxis, spatial associations between heterotrophic bacteria and other species of cyanobacteria occur in aquatic habitats (Paerl \& Gallucci 1985, Stevenson \& Waterbury 2006). However, no quantitative evidence for chemotaxis by heterotrophic bacteria towards the chemical products of Prochlorococcus and Synechococcus populations has yet been reported. An assessment of the behavioural relationships between these important functional units of the microbial food web will aid in obtaining an understanding of how they co-exist, cooperate, or compete in the ocean.

\section{MATERIALS AND METHODS}

Heterotrophic bacteria. Three marine bacterial species, including 2 gammaproteobacteria, Pseudoalteromonas haloplanktis (ATCC700530) and Vibrio alginolyticus (12G01), and 1 alphaproteobacterium, Silicibacter sp. (TM1040), were grown to mid-exponential phase and prepared for chemotaxis studies using previously established protocols. P. haloplanktis was grown in $1 \%$ tryptic soy broth (TSB; Difco) supplemented with $400 \mathrm{mM} \mathrm{NaCl}$. Cells were then diluted 1:20 in artificial seawater (ASW), before being starved for $72 \mathrm{~h}$ (Mitchell et al. 1996). Silicibacter sp. (TM1040) was grown in half-strength 2216 marine broth (Miller et al. 2004), centrifuged at $1500 \times g$ for $5 \mathrm{~min}$ and washed in ASW. V. alginolyticus was grown in Vibrio nine salt solution (VNSS), centrifuged at $1500 \times g$ for 5 min and washed in NSS (Malmcrona-Friberg et al. 1990).

Cultivation of Synechococcus and Prochlorococcus extracellular products. Axenic cultures of Synechococcus elongatus (CCMP 1630) and Prochlorococcus marinus strain MED $4 \mathrm{Ax}$ were grown in $\mathrm{f} / 2$ medium and Pro99 medium, respectively, at $20^{\circ} \mathrm{C}$, under constant light conditions $\left(36 \mu \mathrm{E} \mathrm{m}^{-2} \mathrm{~s}^{-1}\right)$ to midexponential growth phase. The extracellular products (culture filtrates) of each strain were obtained using the methods of Bell \& Mitchell (1972). Cells were centrifuged for $5 \mathrm{~min}$ at $500 \times \mathrm{g}$, and $5 \mathrm{ml}$ of a $10 \mathrm{ml}$ total volume were then gently filtered through a syringemounted $0.2 \mu \mathrm{m}$ filter (Pall). To determine the concentration of DOC in each culture filtrate, the filtrate was acidified with phosphoric acid to $\mathrm{pH} 2$, sparged with compressed air to remove inorganic carbon, and measured with a Shimadzu TOC-5000 total carbon analyser. The filtrate, containing the extracellular pro- ducts, was then employed as a chemoattractant for bacteria. While it is possible that during the filtration process some cell lysis may have occurred, cyanobacterial lysis products, occurring as a result of viral infection (Suttle \& Chan 1993, Sullivan et al. 2003), are also likely to represent a significant source of DOC in the environment. For each bacterial species, single control experiments were performed using $f / 2$ and Pro99 media, pre-filtered through $0.2 \mu \mathrm{m}$ membrane filters, to ensure that the cyanobacterial growth media, or extracts from membrane filters, did not provoke chemotactic responses by any of the bacteria.

Chemotaxis assay and image analysis. A microfluidic chemotaxis assay, described in detail elsewhere (Seymour et al. 2008), was applied to study the chemotactic response of the 3 bacterial species to the extracellular chemical products of Synechococcus and Prochlorococcus. The assay employed a $45 \mathrm{~mm}$ long, $3 \mathrm{~mm}$ wide and $50 \mu \mathrm{m}$ deep microchannel (Fig. 1). Two inline inlet ports simultaneously introduced bacteria (Inlet A) and chemoattractants (Inlet B) into the channel, at $240 \mu \mathrm{m} \mathrm{s}^{-1}$ using a syringe pump. Inlet B was joined to a $100 \mu \mathrm{m}$ wide microinjector, which generated a $300 \mu \mathrm{m}$ wide band of chemoattractants in the centre of the channel. Bacteria were advected along either side of the chemoattractant band, until flow in

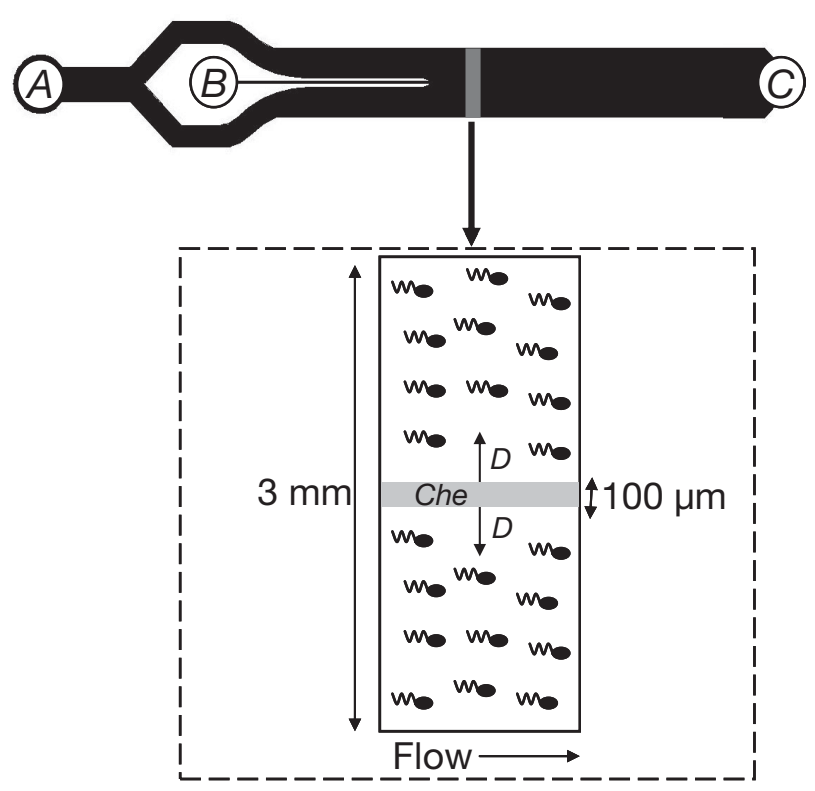

Fig. 1. Microfluidic chemotaxis assay. Bacteria and chemoattractants were injected into the channel via Inlets A and B, respectively. C denotes the channel's outlet. The grey box represents the position $3 \mathrm{~mm}$ downstream of the microinjector's tip where data were acquired. Inset: Magnified schematic of the channel region denoted by the grey box, showing the initial conditions within the channel, including the initial position and width of the chemoattractant band (Che), the direction of flow, and the direction of diffusion of the chemoattractant band (D) at the onset of the experiment 
the channel was stopped when the syringe pump was disengaged. At this point, fluid flow stopped instantaneously and the chemoattractant band spread laterally at a rate set by molecular diffusion, allowing for the chemotactic response of the bacteria to be measured in flow-free conditions.

An inverted microscope (Nikon TE2000e) was used to visualise the positions of bacteria across the channel, and 'movies' (sequences of 200 frames recorded at 32.4 frames $\mathrm{s}^{-1}$ ) were captured at 2 min intervals using a $1600 \times 1200$ pixel CCD camera (PCO 1600, Cooke). Experiments were run for 10 to $12 \mathrm{~min}$, which is consistent with the time period within which maximum chemotactic accumulations of bacteria within the channel return to uniformity as a consequence of the diffusion and uptake of the chemoattractant band (Stocker et al. 2008, Seymour et al. 2009). With the aid of image analysis software (IPlab, BD Biosciences Bioimaging), the mean distribution of bacteria across the channel ( $x$ direction) was recorded at each time point.

Data analysis. To measure the strength of the chemotactic response and compare treatments using a single quantitative parameter, we computed a chemotactic index $I_{\mathrm{C}}=C_{\mathrm{C}} / C_{\mathrm{O}}$, where $C_{\mathrm{C}}$ is the mean cell concentration in the central $600 \mu \mathrm{m}$ of the microchannel, corresponding to the position of the chemoattractant band, and $C_{\mathrm{O}}$ is the mean cell concentration in the outermost $600 \mu \mathrm{m}$ of the channel (corresponding to the upper $600 \mu \mathrm{m}$ in Fig. 1) (Seymour et al. 2008). A uniform cell distribution (no chemotaxis) yields $I_{\mathrm{C}}=1$, whereas strong chemotaxis is characterised by large values of $I_{\mathrm{C}}$. Experiments were conducted in triplicate, and the intensity of the chemotactic responses was compared between bacteria for each chemoattractant by comparing $I_{\mathrm{C}}$ values.

Data were tested for normality using the Kolmogorov-Smirnov test, and where normality was satisfied, $I_{C}$ values for different bacteria were compared using analysis of variance (ANOVA), coupled with Tukey test post hoc analysis. In cases where data were not normally distributed, or the sample size was small, the non-parametric Mann-Whitney test was employed.

\section{RESULTS AND DISCUSSION}

\section{Occurrence of experimental organisms in the environment}

To determine whether the bacterial species used here are representative of those occurring in the oligotrophic ocean, where Prochlorococcus and Synechococcus dominate, we performed an examination of 15 randomly selected open ocean sites, spanning the Atlantic, Indian and Pacific Oceans, from the Global
Ocean Sampling (GOS) data set (Rusch et al. 2007). The Metagenome Rapid Annotation Subsystem Technology (MG-Rast) system was used to Blast protein encoding genes using the SEED framework (Overbeek et al. 2005, Meyer et al. 2008), using a maximum e value of $10^{-5}$ and a minimum alignment length of $50 \mathrm{bp}$. Hits for Silicibacter TM1040 and Pseudoalteromonas haloplanktis occurred within $100 \%$ of the open ocean metagenomes examined, while hits for Vibrio alginolyticus occurred in $93 \%$ of metagenomes. This indicates that the bacterial strains used here widely occur in the oligotrophic open ocean and are likely to co-occur with Synechococcus and Prochlorococcus in the environment.

\section{Chemotactic responses to Synechococcus extracellular exudates}

Synechococcus elongatus is a comparatively large (1 to $3 \mu \mathrm{m}$ ) species of Synechococcus, which occurs widely in both open ocean and coastal environments, typically accounting for $\sim 10 \%$ of total Synechococcus hits in our analysis of GOS samples. In the chemotactic experiments, the extracellular products of $S$. elongatus had a mean DOC concentration of $279 \pm 91$ (SD) $\mu \mathrm{M}$ and elicited a strong and rapid chemotactic response by each of the 3 bacterial isolates (Figs. $2 b \& 3$, Table 1). Dense accumulations of each of the heterotrophic bacterial species occurred within the centre of the microfluidic channel, corresponding to the position of the chemoattractant band, within 2 to 4 min (Fig. 2b). A strong and rapid response was exhibited by Pseudoalteromonas haloplanktis, which has previously been shown to exhibit chemotactic responses to the extracellular products of eukaryotic phytoplankton (Seymour et al. 2009). P. haloplanktis cells accumulated within the band of $S$. elongatus exudates in concentrations of up to 9-fold above background levels (Fig. 3a), reaching a mean $I_{C}$ value of 6.7. This high level of attraction was not significantly different $(p>0.05)$ from that exhibited by Silicibacter TM1040, which also strongly responded to the $S$. elongatus filtrates, reaching a maximum $I_{\mathrm{C}}$ value of 5.9. Vibrio alginolyticus reached a maximum $I_{\mathrm{C}}$ value of 3.4 , which was significantly different $(\mathrm{p}<0.05)$ and weaker than the responses of both other bacteria. No evidence for positive chemotaxis was exhibited by any of the bacterial strains to the control case of $\mathrm{f} / 2$ media $\left(I_{C}=0.7\right.$ to 1.3 ; e.g. Figs. 2a \& 3d), and in each case the chemotactic response to the Synechococcus products was significantly different $(p<0.05)$ from the control.

The rapid positive responses exhibited by all 3 bacterial strains here indicate that the extracellular products of Synechococcus elongatus contain chemical con- 

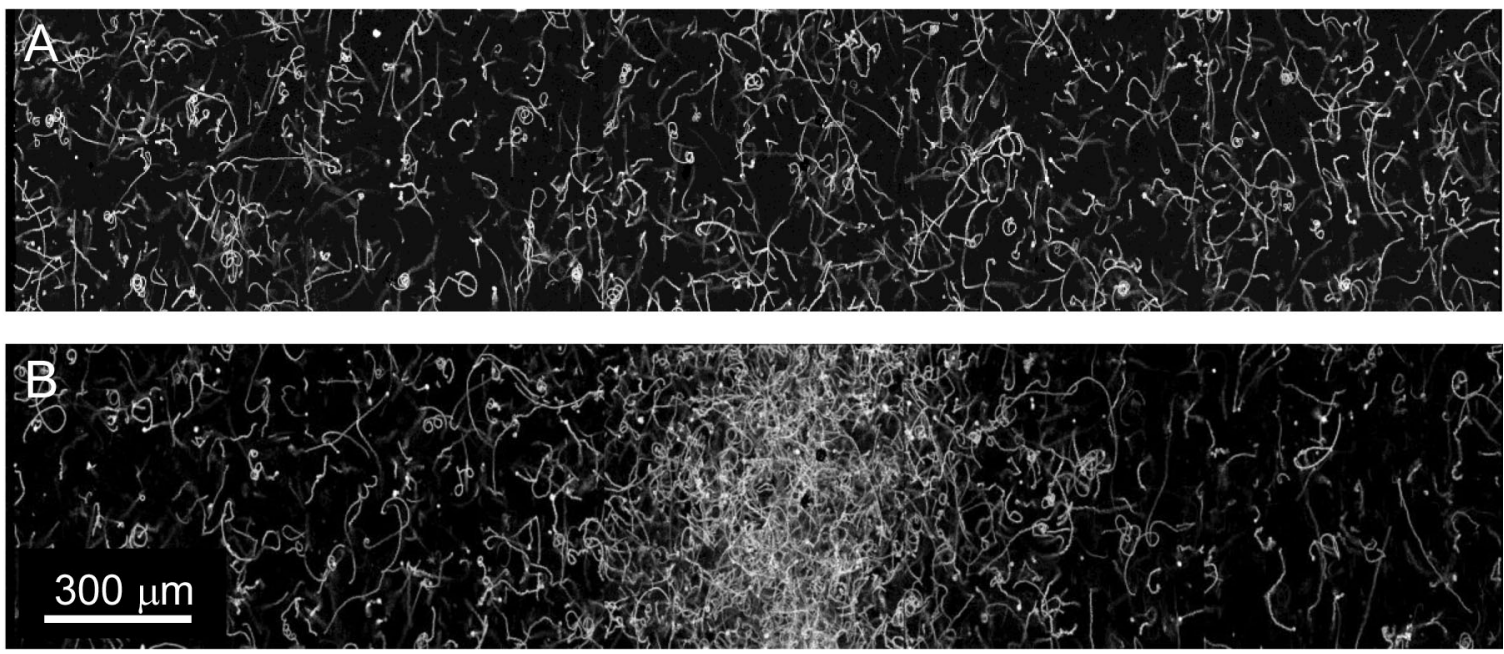

Fig. 2. Silicibacter sp. TM1040. (A) Swimming trajectories of TM1040 cells across the microfluidic channel following injection of $\mathrm{f} / 2$ growth medium as a chemoattractant (control). Each white path is the trajectory of a single bacterium. (B) Swimming trajectories of TM1040 cells within a band of Synechococcus elongatus extracellular products, demonstrating strong accumulation in the band of chemoattractant. Note that the orientation has been rotated $90^{\circ}$ from Fig. 1

stituents that act as strong chemoattractants for these marine bacteria. However, we observed marked differences in the speed of the response, indicating differences in the chemotactic velocity of the 3 bacterial species (see below), with Pseudoalteromonas haloplanktis reaching maximum accumulation within the patch within 2 min, compared to 4 and 8 min for TM1040 and Vibrio alginolyticus, respectively (Table 1).

\section{Chemotactic responses to Prochlorococcus extracellular exudates}

Two of the 3 strains of heterotrophic bacteria also exhibited clear chemotactic responses towards the extracellular products of Prochlorococcus marinus (MED 4Ax; Fig. 4). Silicibacter TM1040, which has previously been shown to use chemotaxis to establish close ecological associations with phytoplankton
(Miller et al. 2004), reached a mean maximum $I_{\mathrm{C}}$ value of 3.1. Pseudoalteromonas haloplanktis also exhibited a positive chemotactic response $\left(I_{\mathrm{C}}=2.4\right)$, which again did not differ significantly from Silicibacter TM1040 ( $p>0.05)$. In contrast, significantly different $(p<0.05)$ and weaker responses were exhibited by Vibrio alginolyticus, which in some cases showed a short-lived minor response (Fig. 4c), but typically displayed $I_{\mathrm{C}}$ values only marginally above 1 (Table 1) and not significantly different $(p>0.05)$ from the control case, where Pro99 medium was used as a chemoattractant $\left(I_{\mathrm{C}}=0.9\right.$ to 1.4$)$.

In line with the Synechococcus filtrate experiments, Pseudoalteromonas haloplanktis, once again reached maximum accumulation levels faster than the other 2 bacterial strains (Table 1). Variability in response time is driven by differences in the chemotactic velocity of the bacterial populations (Rivero et al. 1989), which is a fraction (typically 5 to $35 \%$, Ahmed \& Stocker 2008) of

Table 1. Mean values of the chemotactic index $I_{\mathrm{C}}$ for heterotrophic bacteria responding to the extracellular chemical products of Synechococcus and Prochlorococcus. Mean \pm SD were calculated from triplicate experiments. Time: time elapsed since release of the chemoattractant

\begin{tabular}{|c|c|c|c|c|c|c|}
\hline \multirow{2}{*}{$\begin{array}{l}\text { Time } \\
\text { (min) }\end{array}$} & \multicolumn{3}{|c|}{ Synechococcus - } & \multicolumn{3}{|c|}{ Prochlorococcus } \\
\hline & $\begin{array}{c}\text { Pseudoalteromonas } \\
\text { haloplanktis }\end{array}$ & $\begin{array}{l}\text { Silicibacter sp. } \\
\text { TM1040 }\end{array}$ & $\begin{array}{c}\text { Vibrio } \\
\text { alginolyticus }\end{array}$ & $\begin{array}{c}\text { Pseudoalteromonas } \\
\text { haloplanktis }\end{array}$ & $\begin{array}{l}\text { Silicibacter } \text { sp. } \\
\text { TM1040 }\end{array}$ & $\begin{array}{c}\text { Vibrio } \\
\text { alginolyticus }\end{array}$ \\
\hline 2 & $6.7 \pm 1.8$ & $4.2 \pm 1.4$ & $1.2 \pm 0.2$ & $2.4 \pm 0.1$ & $2.7 \pm 0.5$ & $1.2 \pm 0.3$ \\
\hline 4 & $6.6 \pm 1.2$ & $5.9 \pm 2.4$ & $1.9 \pm 0.4$ & $2.0 \pm 0.3$ & $3.1 \pm 0.9$ & $1.2 \pm 0.7$ \\
\hline 6 & $4.2 \pm 1.0$ & $5.6 \pm 2.9$ & $2.7 \pm 0.9$ & $1.8 \pm 0.2$ & $2.2 \pm 0.4$ & $0.9 \pm 0.4$ \\
\hline 8 & $2.7 \pm 0.3$ & $4.1 \pm 1.8$ & $3.4 \pm 2.4$ & $1.5 \pm 0.3$ & $2.1 \pm 0.5$ & $0.6 \pm 0.1$ \\
\hline 10 & $2.0 \pm 0.2$ & $3.6 \pm 1.5$ & $3.3 \pm 1.1$ & $1.3 \pm 0.1$ & $1.7 \pm 0.3$ & $0.7 \pm 0.2$ \\
\hline
\end{tabular}



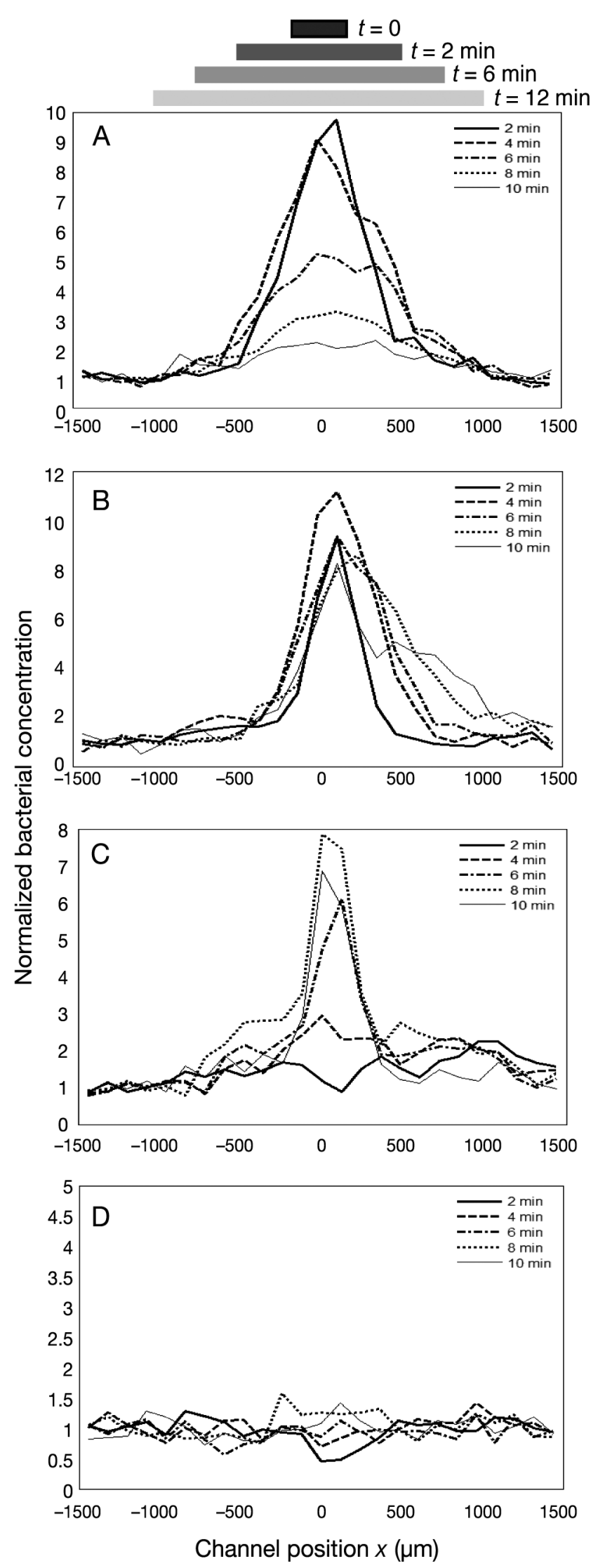

the bacterial swimming speed, but also depends on chemoreceptor sensitivity. The mean swimming speed of $P$. haloplanktis $\left(85 \mu \mathrm{m} \mathrm{s}^{-1}\right)$ was substantially higher than both Silicibacter TM1040 $\left(52 \mu \mathrm{m} \mathrm{s}^{-1}\right)$ and Vibrio alginolyticus $\left(54 \mu \mathrm{m} \mathrm{s} \mathrm{s}^{-1}\right)$, indicating that swimming speeds indeed had a bearing on the rate of the chemotactic response. This supports the hypothesis that where nutrient pulses are rapidly dissipated by physical processes including diffusion and turbulence (e.g. the ocean), fast swimming speeds will be advantageous for rapid exploitation by bacteria (Stocker et al. 2008).

\section{Ecological implications}

The experiments presented here provide the first quantitative evidence for bacterial chemotaxis in response to the chemical products of the important marine genera Synechococcus and Prochlorococcus. The extracellular products of Synechococcus and Prochlorococcus are primarily composed of low molecular weight DOC compounds, which are highly labile substrates for heterotrophic bacteria (Chang 1981, Bertilsson et al. 2005). The release of these chemical products into the water column may occur as a consequence of both extracellular exudation and cell lysis. Particularly in oligotrophic waters, the chemical products from these cyanobacterial groups are expected to represent an essential pool of DOC for heterotrophic bacterial growth (Bertilsson et al. 2005). Therefore, chemotactic responses to the DOC released from Synechococcus and Prochlorococcus cells may provide a strong competitive advantage for some heterotrophic bacteria, which will gain exposure to elevated nutrient concentrations before their competitors (Stocker et al. 2008).

In the dynamic ocean environment, however, physical constraints must be considered when extrapolating chemotaxis to potential localised associations of cells.

Fig. 3. Representative distributions of bacteria across the width of the microfluidic channel at different times following the injection of a band of Synechococcus elongatus filtrates. The chemoattractant band was initially between $x= \pm 150 \mu \mathrm{m}$, and $t=0$ corresponds to the release of the chemoattractant band when flow in the channel was stopped. Bacterial concentrations were normalised to the mean concentration measured in the $600 \mu \mathrm{m}$ closest to the right wall of the microchannel. (A) Pseudoalteromonas haloplanktis, (B) Silicibacter sp. TM1040, (C) Vibrio alginolyticus, (D) an example of control experiment, where TM1040 bacteria were presented with a band of $f / 2$ growth medium, demonstrating the lack of chemotactic response. Bars above panel (A) represent the width of the diffusing chemoattractant band at different times during the experiment 

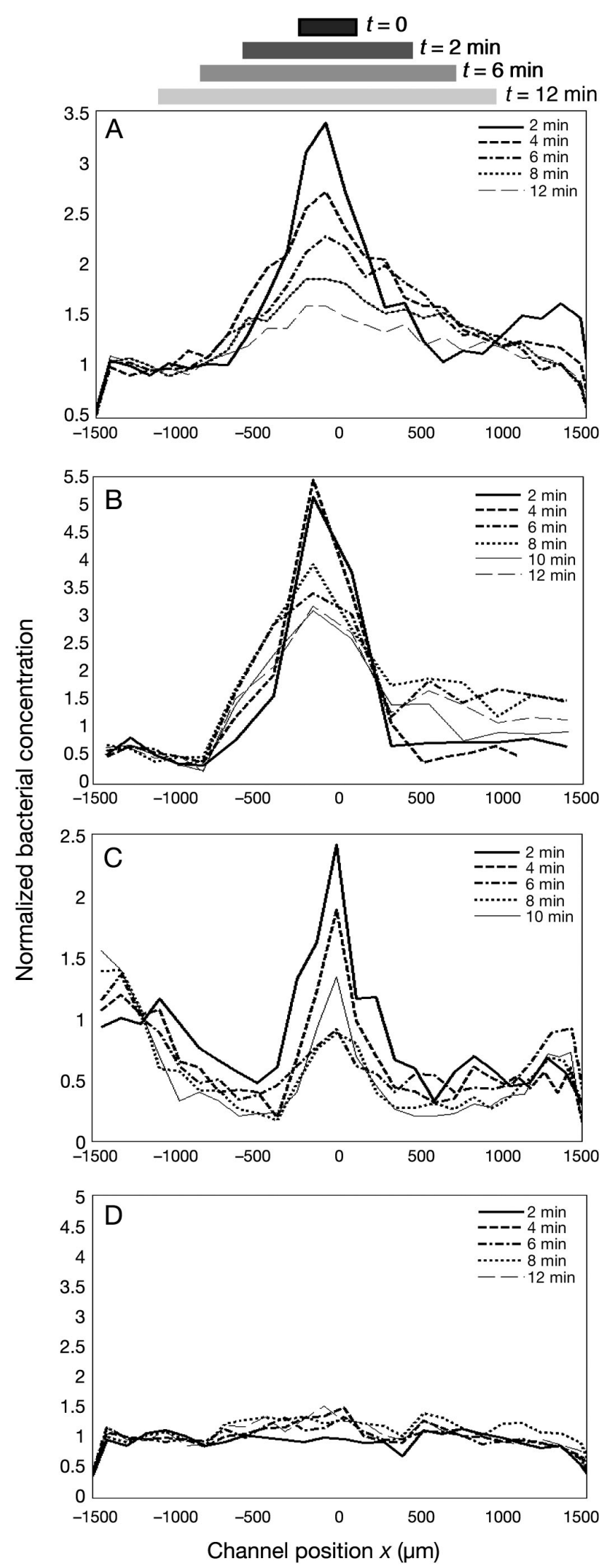

It has previously been calculated that the smallest nutrient microzone that a swimming bacterium could detect in the ocean would correspond to a $2 \mu \mathrm{m}$ radius phytoplankton cell (Jackson 1987). Prochlorococcus and Synechococcus cells are typically only 0.6 to $1.5 \mu \mathrm{m}$. However, these previous calculations considered a bacterium with the swimming characteristics of Escherichia coli. It is now recognised that marine bacteria, including the strains studied here, exhibit markedly different chemotactic behaviours than $E$. coli (Barbara \& Mitchell 2003a, Stocker et al. 2008). Mitchell et al. (1996) suggested that the rapid reaction times exhibited by marine bacteria allow them to sense and cluster within nutrient patches associated with cells down to the size of Prochlorococcus and Synechococcus.

Using atomic force microscopy, Malfatti \& Azam (2009) recently demonstrated that localised associations between individual Synechococcus cells and heterotrophic bacteria can indeed commonly occur in the ocean. Such microscale associations may have significant implications for nutrient cycling rates and microbial competition. The chemotactic behaviour exhibited here provides a potential mechanism for the development of these associations.

The strength of bacterial chemotactic responses in the environment will ultimately depend upon the concentration of labile organic material within the cyanobacterial chemical products. In our experiments, the mean DOC concentration in the Synechococcus and Prochlorococcus culture filtrates was 279 and $133 \mu \mathrm{M}$, respectively. While these DOC values are about 3- to 5-fold higher than open ocean bulk concentrations (Wiebinga \& de Baar 1998, Doval et al. 2001), they are well within the range of DOC concentrations observed during phytoplankton blooms (Gobler et al. 2004, Packard et al. 2000). In the environment, associations between heterotrophs and cyanobacteria occur in a microenvironmental scenario, where the concentrations of exudates near the surfaces of cells will be substantially higher than in the bulk phase. Furthermore, there is both in situ (Seymour et al. 2005) and experimental (Koblî̈ek et al. 2000) evidence for the existence of localised aggregations of Synechococcus cells, which will generate larger and more concentrated clouds of DOC than are produced by individual cells (Rothschild et al. 1999). The DOC concentrations

Fig. 4. As in Fig. 3, but following the injection of a band of Prochlorococcus MED 4Ax filtrates. (A) Pseudoalteromonas haloplanktis, (B) Silicibacter sp. TM1040, (C) Vibrio alginolyticus, (D) an example of control experiment, where TM1040 bacteria were presented with a band of Pro99 growth medium, demonstrating the lack of chemotactic response 
in these scenarios are likely comparable to, or higher than, the DOC concentrations applied in these experiments, and we propose that the strong behavioural responses observed here are also likely to occur in the environment. These observations, along with recent demonstrations of microscale associations (Seymour et al. 2005, Malfatti \& Azam 2009) and evidence of mutualistic relationships (Morris et al. 2008), suggest the need for a closer examination of the ecological and biogeochemical ties between heterotrophic bacteria and these 2 important groups of marine cyanobacteria.

Acknowledgements. D. Sher and S.W. Chisholm kindly provided the Prochlorococcus culture and helpful comments on the manuscript. We also thank M. Polz, D.E. Hunt and R. Belas for providing bacterial strains and L. Fernandez for assistance with DOC measurements. This research was funded by NSF grants OCE-0526241 and OCE-0744641 CAREER to R.S., a Martin Fellowship for Sustainability to T.A., a National Defence Science and Engineering Graduate (NDSEG) Fellowship to W.M.D. and Australian Research Council Discovery Grant DP0772186 to J.R.S.

\section{LITERATURE CITED}

Ahmed T, Stocker R (2008) Experimental verification of the behavioural foundation of bacterial transport parameters using microfluidics. Biophys J 95:4481-4493

Alavi M, Miller T, Erlandson K, Schneider R, Belas R (2001) Bacterial community associated with Pfiesteria-like dinoflagellate cultures. Environ Microbiol 3:380-396

Azam F, Ammerman JW (1984) Cycling of organic matter by bacterioplankton in pelagic marine ecosystems: microenvironmental considerations. In Fasham MJR (ed) Flows of energy and materials in marine ecosystems. Plenum Press, New York, p 345-360

Barbara GM, Mitchell JG (2003a) Marine bacterial organisation around point-like sources of amino acids. FEMS Microbiol Ecol 43:99-109

Barbara GM, Mitchell JG (2003b) Bacterial tracking of motile algae. FEMS Microbiol Ecol 44:79-87

Bell W, Mitchell R (1972) Chemotactic and growth responses of marine bacteria to algal extracellular products. Biol Bull (Woods Hole) 143:265-277

Bertilsson S, Berglund O, Pullin MJ, Chisholm SW (2005) Release of dissolved organic matter by Prochlorococcus. Vie Milieu 55:225-231

Blackburn N, Fenchel T, Mitchell JG (1998) Microscale nutrient patches in plankton habitats shown by chemotactic bacteria. Science 282:2254-2256

Chang TP (1981) Excretion and DOC utilization by Oscillatoria rubescens and its accompanying micro-organisms. Arch Hydrobiol 91:509-520

Chisholm SW, Olsen RJ, Zettler ER, Goerick R, Waterbury JB, Welschrieger NA (1988) A novel free-living prochlorophyte abundant in the oceanic euphotic zone. Nature 334:340-343

- Doval MD, Álvarez-Salgado XA, Gasol JM, Lorenzo LM, Mirón I, Figueiras FG, Pedrós-Alió C (2001) Dissolved and suspended organic carbon in the Atlantic sector of the Southern Ocean. Stock dynamics in upper ocean waters. Mar Ecol Prog Ser 223:27-38

Fernández E, Marañón E, Morán XAG, Serret P (2003) Poten- tial causes for the unequal contribution of picophytoplankton to total biomass and productivity in oligotrophic waters. Mar Ecol Prog Ser 254:101-109

- Gobler CJ, Boneillo GE, Debenham CJ, Caron DA (2004) Nutrient limitation, organic matter cycling, and plankton dynamics during an Aureococcus anophagefferens bloom. Aquat Microb Ecol 35:31-43

Jackson GA (1987) Simulating chemosensory responses of marine microorganisms. Limnol Oceanogr 32:1253-1266

Koblî̈lek M, Komenda J, Masojidek J, Pechar L (2000) Cell aggregation of the cyanobacterium Synechococcus elongatus. Role of electron transport chain. J Phycol 36: 662-668

> Malfatti F, Azam F (2009) Atomic force microscopy reveals microscale networks and possible symbioses among pelagic marine bacteria. Aquat Microb Ecol 58:1-14

Malmcrona-Friberg K, Goodman A, Kjelleberg S (1990) Chemotactic responses of marine Vibrio sp. strain S14 (CCUG 15956) to low-molecular weight substances under starvation and recovery conditions. Appl Environ Microbiol 56:3699-3704

Meyer F, Paarmann D, D'Souza M, Olson R and others (2008) The metagenomics RAST server-a public resource for the automatic phylogenetic and functional analysis of metagenomes. BMC Bioinformatics 9:386

Miller TR, Hnilicka K, Dziedzic A, Desplats P, Belas R (2004) Chemotaxis of Silicibacter sp. strain TM1040 toward dinoflagellate products. Appl Environ Microbiol 70: 4692-4701

Mitchell JG, Pearson L, Dillon S (1996) Clustering of marine bacteria in seawater enrichments. Appl Environ Microbiol 62:3716-3721

Morris JJ, Kirkegaard R, Szul MJ, Johnson ZI, Zinser ER (2008) Facilitation of robust growth of Prochlorococcus colonies and dilute liquid cultures by 'helper' heterotrophic bacteria. Appl Environ Microbiol 74:4530-4534

Overbeek R, Begley T, Butler RM, Choudhuri JV and others (2005) The subsystems approach to genome annotation and its use in the project to annotate 1000 genomes. Nucleic Acids Res 33:5691-5702

> Packard T, Chen W, Blasco D, Savenkoff C and others (2000) Dissolved organic carbon in the Gulf of St. Lawrence. Deep-Sea Res II 47:435-459

Paerl HW, Gallucci KK (1985) Role of chemotaxis in establishing a specific nitrogen-fixing cyanobacterial-bacterial association. Science 227:647-649

Paerl HW, Pinckney JL (1996) A mini-review of microbial consortia: their roles in aquatic production and biogeochemical cycling. Microb Ecol 31:225-247

Rivero MA, Tranquillo TT, Buettner HM, Lauffenburger DA (1989) Transport models for chemotactic cell populations based on individual cell behaviour. Chem Eng Sci 44: 2881-2897

Rothschild BJ, Haley PJ, Cai D (1999) Influence of physical forcing on microclouds of dissolved organic matter and nutrients in the ocean. J Plant Res 21:1217-1230

> Rusch DB, Halpern AL, Sutton G, Heidelberg KB and others (2007) The Sorcerer II Global Ocean Sampling Expedition: Northwest Atlantic through eastern tropical Pacific. PLoS Biol 5:e77, doi:10.1371/journal.pbio.0050077

> Seymour JR, Seuront L, Mitchell JG (2005) Microscale and small-scale temporal dynamics of a coastal planktonic microbial community. Mar Ecol Prog Ser 300:21-37

Seymour JR, Ahmed T, Marcos, Stocker R (2008) A microfluidic chemotaxis assay to study microbial behaviour in diffusing nutrient patches. Limnol Oceanogr Methods 6: $477-488$ 
Seymour JR, Marcos, Stocker R (2009) Resource patch formation and exploitation throughout the marine microbial food web. Am Nat 173:E15-E29

Stevenson BS, Waterbury JB (2006) Isolation and identification of an epibiotic bacterium associated with heterocystous Anabaena cells. Biol Bull (Woods Hole) 210:73-77

Stocker R, Seymour JR, Samadani A, Hunt DH, Polz M (2008) Rapid chemotactic response enables marine bacteria to exploit ephemeral microscale nutrient patches. Proc Natl Acad Sci 105:4209-4214

Sullivan MB, Waterbury JB, Chisholm SW (2003) Cyanophages infecting the oceanic cyanobacterium Prochlorococcus. Nature 424:1047-1051

Editorial responsibility: Fereidoun Rassoulzadegan, Villefranche-sur-Mer, France
Suttle CA, Chan AM (1993) Marine cyanophages infecting oceanic and coastal strains of Synechococcus: abundance, morphology, cross-infectivity and growth characteristics. Mar Ecol Prog Ser 92:99-109

Vaulot D, Marie D, Olson RJ, Chisholm SW (1995) Growth of Prochlorococcus, a photosynthetic prokaryote, in the equatorial Pacific Ocean. Science 268:1480-1482

Waterbury JB, Watson SW, Guillard RRL, Brand LE (1979) Wide-spread occurrence of a unicellular, marine cyanobacterium. Nature 277:293-294

Wiebinga CJ, de Baar HJW (1998) Determination of the distribution of dissolved organic carbon in the Indian sector of the Southern Ocean. Mar Chem 61:185-201

Submitted: July 21, 2009; Accepted: January 12, 2010

Proofs received from author(s): March 29, 2010 